\title{
Activity of Ni Substituted Ca-La-hexaaluminate Catalyst in Dry Reforming of Methane
}

\author{
K. Ikkour $\cdot$ D. Sellam $\cdot$ A. Kiennemann $\cdot$ \\ S. Tezkratt $\cdot$ O. Cherifi
}

Received: 8 April 2009/Accepted: 9 July 2009/Published online: 21 July 2009

(C) The Author(s) 2009. This article is published with open access at Springerlink.com

\begin{abstract}
Ca}_{1-x} \mathrm{La}_{x} \mathrm{NiAl}_{11} \mathrm{O}_{19-\delta}(\mathrm{O} \leq x \leq 1)$ hexaaluminate oxydes were synthesized starting from nitrate salts of $\mathrm{Ca}, \mathrm{La}, \mathrm{Ni}$ and $\mathrm{Al}$ precipitated by citric acid. After calcination they were used as catalysts precursors in dry reforming of methane to synthesis gas at atmospheric pressure $\left(600-800{ }^{\circ} \mathrm{C}\right)$ with a mixture of $\mathrm{CH}_{4} / \mathrm{CO}_{2} / \mathrm{Ar}: 1 / 1 / 3$. The solids were characterized by X-ray diffraction (XRD), BET surface area, temperature programmed reaction and oxidation (TPO) and by X-ray photoelectron spectroscopy. XRD analysis shows a pure hexaluminate phase as soon as a part of calcium has been substituted by lanthanum. After $\mathrm{H}_{2}$ reduction and after reactivity test, Ni metal characterized by XRD is responsible of the high activity (equilibrium conversion near $100 \%$ at $800{ }^{\circ} \mathrm{C}$ ). Ni hexaaluminate shows a remarkable high stability (more than $300 \mathrm{~h}$ test) probably due to the low formation of surface carbon (TPO).
\end{abstract}

Keywords Hexaaluminates - Catalyst - Methane · Syn gas

\section{Introduction}

Natural gas is recognized as one of the fuel of the near future due to the worldwide proven reserve [1]. This situation has produced a growing interest in the development

K. Ikkour $\cdot$ D. Sellam $\cdot$ S. Tezkratt $(\bowtie) \cdot$ O. Cherifi

Laboratoire de Recherche de Chimie Appliquée et Génie

Chimique, Université M. Mammeri, Tizi-Ouzou, Algeria

e-mail: saidtezkratt@yahoo.fr

A. Kiennemann

Laboratoire Matériaux, Surfaces, Procédés Pour la Catalyse

(LMSPC), Université de Strasbourg, 25 Rue Becquerel,

67087 Strasbourg Cedex 2, France of technologies able to transform natural gas to liquid energy through the syngas. Dry reforming $\left(\mathrm{CH}_{4}+\mathrm{CO}_{2} \rightarrow\right.$ $2 \mathrm{CO}+2 \mathrm{H}_{2} \Delta \mathrm{H}_{298}=247 \mathrm{~kJ} \mathrm{~mol}^{-1}$ ) produces syngas with a $\mathrm{H}_{2} / \mathrm{CO}$ ratio near 1 favourable for Fischer-Tropsch or hydrocarbonylation reactions. Dry reforming could also have environmental implication by the thermochemical valorisation of $\mathrm{CO}_{2}$. However, one disadvantage of dry reforming is the accumulation of carbon by methane cracking or $\mathrm{CO}$ disproportion over catalytic surface. Coke deposition is strongly influenced by the type of metal used. Noble metals present lower level of coke than nickel [2], however, Ni is generally used because of it low cost and availability [3]. Carbon formation decreases with high nickel dispersion, basic supports, redox promoters [4-6] and also if catalyst presents a strong interaction between nickel and the support. This last feature is obtained when nickel is initially present in a defined structure like perovskite [7], spinel [8], fluorite [9] or in a solid solution (NiO-MgO) [5]. With these structures, metal reduction temperature is increased at a temperature near of the reaction temperature and highly dispersed metallic nanoparticles are produced. The presence of alkali earth or rare earth favours carbonates or oxycarbonates formation and it is well documented that such species react with carbon with $\mathrm{CO}$ formation [10].

Hexaaluminates materials $\mathrm{ANiAl}_{11} \mathrm{O}_{19-\delta}(\mathrm{A}=\mathrm{La}, \mathrm{Ca}$, $\mathrm{Ba}, \mathrm{Sr})$ are defined structures, they contain alkali or rare earth oxides and $\alpha$-alumina has been indicated as preventing coke formation [11]. Consequently they are potential candidates to dry reforming. In fact, $\mathrm{LaNi}_{y}$ $\mathrm{Al}_{12-\mathrm{y}} \mathrm{O}_{19-\delta}(y=0.3 ; 0.6 ; 0.9$ and 1$)$ in which $\mathrm{Ni}$ ion is inlayed in hexaaluminate lattice to substitute part of $\mathrm{Al}$ ions are of interest and high resistance to carbon deposition and long term stability $(300 \mathrm{~h})$ were observed for $\mathrm{La}_{0.8} \mathrm{Pr}_{0.2} \mathrm{NiAl}_{11} \mathrm{O}_{19-\delta}[12,13]$. In the present study, a 
series of CaLaNi hexaaluminate were prepared by substitution of $\mathrm{Ca}$ by $\mathrm{La}$, characterized and tested in dry reforming of methane in order to investigate the influence of the presence of $\mathrm{La}$ in the $\mathrm{CaNi}$ hexaaluminate structure on the catalytic dry reforming activity and on the carbon deposition resistance.

\section{Experimental}

\subsection{Catalyst Preparation}

The hexaaluminate $\mathrm{Ca}_{1-x} \mathrm{La}_{x} \mathrm{NiAl}_{11} \mathrm{O}_{19-\delta}(\mathrm{O} \leq x \leq 1)$ were prepared as follows: calcium, lanthanum, nickel and aluminium nitrates were dissolved separately in distilled water mixed together to obtain a molar ratio $\mathrm{Ca} / \mathrm{La} / \mathrm{Ni} / \mathrm{Al}$ equal to $(1-x) / x / 1 / 11$, respectively. The aqueous solution was slowly added at room temperature to citric acid and heated at $60{ }^{\circ} \mathrm{C}$ under stirring to remove excess of water and until formation of a vitreous gel. The gel was then dried at $110{ }^{\circ} \mathrm{C}$ overnight and calcined $2 \mathrm{~h}$ at $500{ }^{\circ} \mathrm{C}$ then $8 \mathrm{~h}$ to $1,100{ }^{\circ} \mathrm{C}$.

\subsection{Catalyst Characterization}

XRD patterns have been obtained using SIEMENS D500 difractometer $(\mathrm{CuK} \alpha$ radiation : $\lambda=1.5418 \AA)$. The obtained phases were determined using fishier ASTM programs (American Society for Testing Material) type DATA FILE PDF Diffraction 2000.

BET surface areas were determined by nitrogen adsorption using Coulter SA 3100 apparatus. Low specific surface areas were obtained (1-6 $\mathrm{m}^{2}$ gcat $^{-1}$, for all samples). Binding energy and chemical composition of surface were measured by XPS (Thermo VG Multilab 2000 using AlKa radiation).

The reducibility of Ni hexaaluminates was studied by TPR and carbon entities formation was determined by TPO as follow: $0.5 \mathrm{~g}$ of catalyst was embedded in a quartz reactor (inner diameter $6.6 \mathrm{~mm}$ ). After purge by argon, the catalyst was heated from room temperature to $900{ }^{\circ} \mathrm{C}$ $\left(15{ }^{\circ} \mathrm{C} \mathrm{min}{ }^{-1}\right)$ in a $\mathrm{H}_{2} / \mathrm{Ar}$ mixture $\left(2 / 50 \mathrm{~mL} \mathrm{~min}^{-1}\right)$ for TPR and in a $5 / 45 \mathrm{~mL} \mathrm{~min}^{-1} \mathrm{O}_{2} / \mathrm{Ar}$ mixture for TPO measurements. In both cases, effluent gas composition was analyzed using TCD gas chromatograph.

\subsection{Catalytic Activity Test}

$\mathrm{CH}_{4} / \mathrm{CO}_{2}$ activities were performed in a fixed-bed quartz reactor under atmospheric pressure. $0.05 \mathrm{~g}$ of catalyst was first reduced in pure $\mathrm{H}_{2}$ flow $\left(1 \mathrm{~L} \mathrm{~h}^{-1}\right)$ at $900{ }^{\circ} \mathrm{C}, 1 \mathrm{~h}$ then purged by $\mathrm{Ar}$ and cooled at room temperature for
15 min. Dry reforming gas $\left(\mathrm{CH}_{4} / \mathrm{CO}_{2} / \mathrm{Ar}: 1 / 1 / 3\right.$; total flow $20 \mathrm{~L} \mathrm{~h}^{-1} \mathrm{gcat}^{-1}$ ) was then admitted at $800{ }^{\circ} \mathrm{C}$ temperature. The catalytic activities were investigated between 500 and $900{ }^{\circ} \mathrm{C}$. The reactants $\left(\mathrm{CH}_{4}\right.$ and $\left.\mathrm{CO}_{2}\right)$ and products $\left(\mathrm{CO}, \mathrm{CO}_{2}, \mathrm{H}_{2}\right)$ were analyzed on line using TCD gas chromatograph equipped with a Carbosieve column.

\section{Results and Discussion}

\subsection{XRD}

Figure 1 shows the XRD patterns of $\mathrm{Ca}_{1-x} \mathrm{La}_{x} \mathrm{NiAl}_{11} \mathrm{O}_{19-\delta}$ hexaaluminates $(0 \leq x \leq 1)$ after calcination at $1,100{ }^{\circ} \mathrm{C}$. For $\mathrm{LaNiAl}_{11} \mathrm{O}_{19-\delta}$ a pure hexaaluminate phase is formed with characteristic diffraction peaks at $36.08 ; 34.02$ and $32.06(2 \theta)$. For $\mathrm{CaNiAl}_{11} \mathrm{O}_{19-\delta}$, we characterize hexaaluminate with low cristallinity, $\alpha-\mathrm{Al}_{2} \mathrm{O}_{3}$ and $\mathrm{NiAl}_{2} \mathrm{O}_{4}$ spinel diffraction peaks localized at $25.3(2 \theta)$ and $37.1(2 \theta)$. In accordance with the literature [14] a $\mathrm{A}^{3+}$ cation can promote the formation of $\mathrm{Ni}$ hexaaluminate more effectively than $\mathrm{A}^{2+}$ cation and as soon few amounts of $\mathrm{La}^{3+}$ is added $(x=0.1) \mathrm{Ni}$ hexaluminate structure is well crystallized.

As shown in Figs. 2 and 3, the Ni hexaaluminate structure is always present after reduction (until $900{ }^{\circ} \mathrm{C}$ ) and after dry reforming. After TPR, it is observed at $44.5(2 \theta)$ the characteristic peak of Ni metal. In fact, only a part of the $\mathrm{Ni}^{2+}$ of the hexaluminate structure has been reduced to $\mathrm{Ni}^{\circ}$ and this will change slightly with the $\mathrm{La}^{3+}$ content. In Fig. 3, Ni metal is always present at $44.5(2 \theta)$ and a characteristic peak of carbon at $26.8^{\circ}(2 \theta)$ is evidenced. The intensity of this peak depends of the La content and carbon deposition seems particularly important on $\mathrm{Ca}_{0.7} \mathrm{La}_{x .3-}$ $\mathrm{NiAl}_{11} \mathrm{O}_{19-\delta}$.

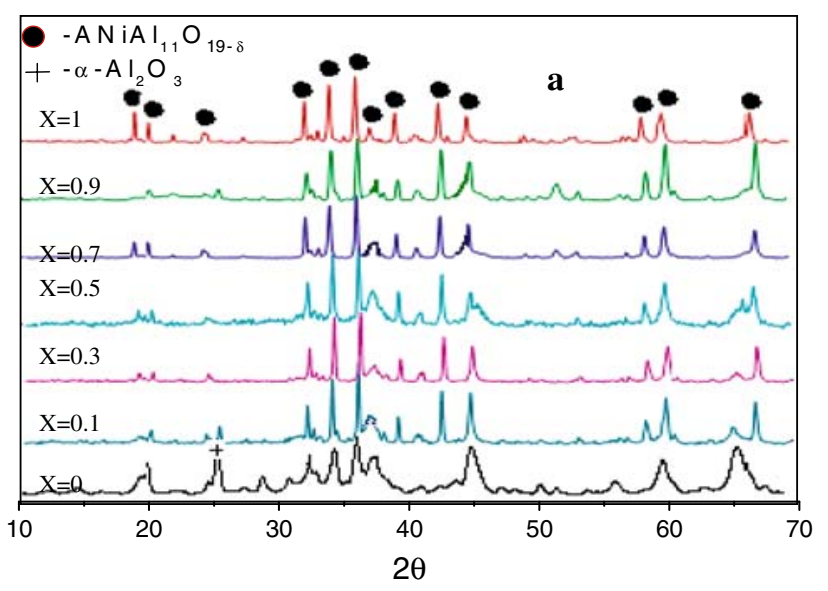

Fig. 1 XRD spectra of calcined $\mathrm{Ca}_{1-x} \mathrm{La}_{x} \mathrm{NiAl}_{11} \mathrm{O}_{19-\delta}$ structure 


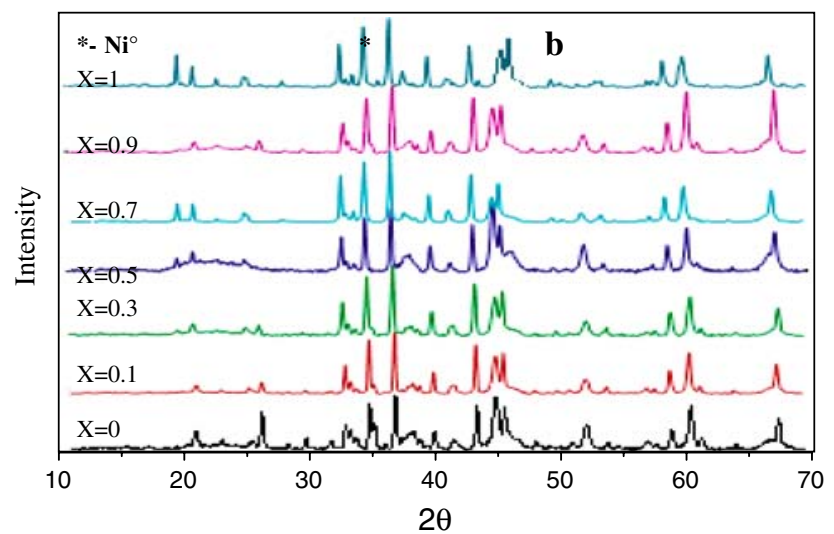

Fig. 2 XRD spectra of $\mathrm{Ca}_{1-x} \mathrm{La}_{x} \mathrm{NiAl}_{11} \mathrm{O}_{19-\delta}$ after TPR

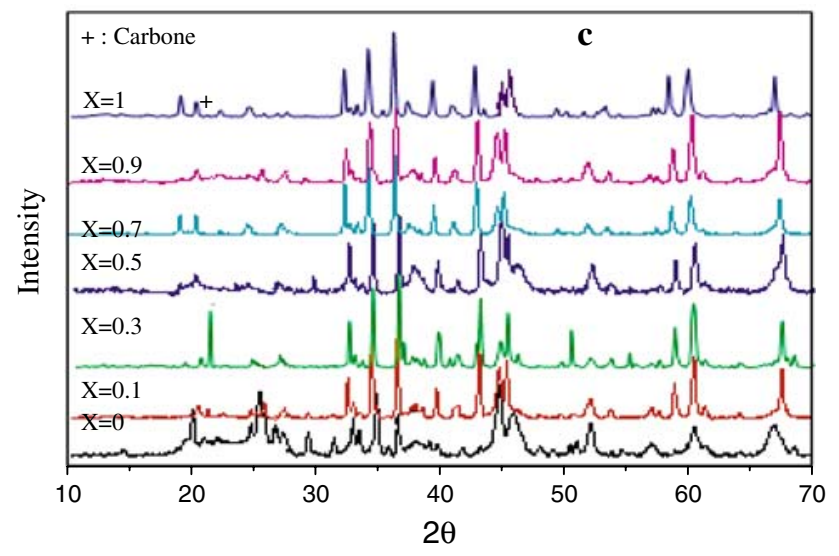

Fig. 3 XRD spectra of $\mathrm{Ca}_{1-x} \mathrm{La}_{x} \mathrm{NiAl}_{11} \mathrm{O}_{19-\delta}$ after reactivity tests

\subsection{TPR}

TPR profiles of $\mathrm{La}_{1-x} \mathrm{La}_{x} \mathrm{NiAl}_{11} \mathrm{O}_{19-\delta}$ catalysts are reported Fig. 4. For all the catalysts, reducibility of $\mathrm{Ni}$ is only obtained at very high temperature $\left(>800{ }^{\circ} \mathrm{C}\right)$. This clearly indicates that it will be absolutely necessary to reduce all the catalysts before reactivity tests. Maximum of reduction is obtained at nearly $900{ }^{\circ} \mathrm{C}$ compared to $400{ }^{\circ} \mathrm{C}$ for $\mathrm{NiO}$ [11]. The temperature of the maximum does not change a lot.

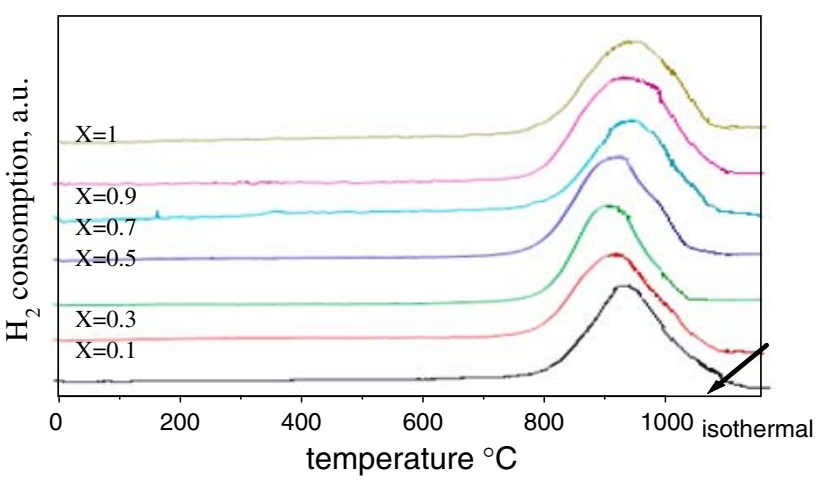

Fig. 4 TPR profiles of $\mathrm{Ca}_{1-x} \mathrm{La}_{x} \mathrm{NiAl}_{11} \mathrm{O}_{19-\delta}$

However, $\mathrm{Ca}_{0.5} \mathrm{La}_{0.5} \mathrm{NiAl}_{11} \mathrm{O}_{19-\delta}$ is reduced at the lowest temperature. The surface reduction changes also with the content of La. From the evaluation surface area of the hydrogen consumption during TPR, reducibility of $\mathrm{Ca}_{0.5} \mathrm{La}_{0.5} \mathrm{NiAl}_{11} \mathrm{O}_{19-\delta}$ is the highest and has been evaluated at $94 \%$ for the nickel. The reduction of the other catalysts has been evaluated between 88 and $92 \%$.

\subsection{XPS}

The binding energy of the elements of the Ni hexaaluminate is given Table 1 . The binding energy of each element is not affected by the Ca substitution by La. For nickel, $\mathrm{Ni} 2 \mathrm{p}_{3 / 2}$ binding energy of $855.5 \mathrm{eV}$ indicates the presence of nickel into the hexaaluminate lattice in the $\mathrm{Ni}^{2+}$ state [15]. $\mathrm{La}, \mathrm{Ca}, \mathrm{Al}$ ions are, respectively, in the $3^{+} ; 2^{+}$and $3^{+}$ oxidation states. Table 2 shows the chemical composition at the catalytic surface.

Surface concentrations of $\mathrm{La}$ and of $\mathrm{Ni}$ are largely lower than nominal composition. This is in accordance with literature data $[15,16]$. It is suggested that segregation of $\mathrm{Ni}$ is driven by difference in binding energies between the respective elements [17]. The $\mathrm{Ni}$ surface concentration increases with the $\mathrm{x}$ value for the same reasons. $\mathrm{Xu}$ et al. [16] have suggested that the surface $\mathrm{Ni}$ concentration correlates with both size and valence of minor cation.
Table 1 Binding energy of surface elements of $\mathrm{Ca}_{1-x} \mathrm{La}_{x} \mathrm{NiAl}_{11} \mathrm{O}_{19-\delta}$ hexaaluminates

\begin{tabular}{lllllll}
\hline $\mathrm{X}$ & Samples & $\mathrm{Ca} 2 \mathrm{p}_{3 / 2}$ & $\mathrm{La}_{5 / 2}$ & $\mathrm{Ni2} \mathrm{p}_{3 / 2}$ & $\mathrm{~A} 2 \mathrm{p}$ & $\mathrm{O} 1 \mathrm{~S}$ \\
\hline 0 & $\mathrm{CaNiAl}_{11} \mathrm{O}_{19}-\delta$ & 347.1 & - & 855.2 & 74.1 & 530.7 \\
0.1 & $\mathrm{Ca}_{0.9} \mathrm{La}_{0.1} \mathrm{NiAl}_{11} \mathrm{O}_{19}-\delta$ & 347.5 & 835.2 & 855.4 & 74.5 & 530.9 \\
0.3 & $\mathrm{Ca}_{0.7} \mathrm{La}_{0.3} \mathrm{NiAl}_{11} \mathrm{O}_{19}-\delta$ & 347.5 & 835 & 855.5 & 74.6 & 531 \\
0.5 & $\mathrm{Ca}_{0.5} \mathrm{La}_{0.5} \mathrm{NiAl}_{11} \mathrm{O}_{19}-\delta$ & 347.5 & 835 & 855.5 & 74.5 & 531 \\
0.7 & $\mathrm{Ca}_{0.3} \mathrm{La}_{0.7} \mathrm{NiAl}_{11} \mathrm{O}_{19}-\delta$ & 347.4 & 835 & 855.5 & 74.6 & 531 \\
0.9 & $\mathrm{Ca}_{0.3} \mathrm{La}_{0.7} \mathrm{NiAl}_{11} \mathrm{O}_{19}-\delta$ & 347.2 & 835 & 855.3 & 74.7 & 531 \\
1 & $\mathrm{LaNiAl}_{11} \mathrm{O}_{19}-\delta$ & - & 835.5 & 855.3 & 74.6 & 531 \\
\hline
\end{tabular}


Table 2 Surface compositions of $\mathrm{Ca}_{1-x} \mathrm{La}_{x} \mathrm{NiAl}_{11} \mathrm{O}_{19-\delta}$ hexaaluminates (theoretical and as determined by XPS)

\begin{tabular}{|c|c|c|c|c|c|c|c|c|c|c|c|}
\hline \multicolumn{2}{|c|}{ Elements } & \multicolumn{2}{|c|}{$\mathrm{Ca}(\%)$} & \multicolumn{2}{|c|}{$\mathrm{La}(\%)$} & \multicolumn{2}{|c|}{$\mathrm{Ni}(\%)$} & \multicolumn{2}{|c|}{$\mathrm{Al}(\%)$} & \multicolumn{2}{|l|}{$\mathrm{O}(\%)$} \\
\hline$X$ & Samples & Surf & Theor & Surf & Theor & Surf & Theor & Surf & Theor & Surf & Theor \\
\hline 0 & $\mathrm{CaNiAl}_{11} \mathrm{O}_{19}-\delta$ & 5 & 5.78 & - & - & 0.9 & 8.48 & 44 & 42.93 & 50.1 & 42.81 \\
\hline 0.1 & $\mathrm{Ca}_{0.9} \mathrm{La}_{0.1} \mathrm{NiAl}_{11} \mathrm{O}_{19-\delta}$ & 4.43 & 5.12 & 0.1 & 1.97 & 1.08 & 8.35 & 44.15 & 42.28 & 50.24 & 42.28 \\
\hline 0.3 & $\mathrm{Ca}_{0.7} \mathrm{La}_{0.3} \mathrm{NiAl}_{11} \mathrm{O}_{19}-\delta$ & 3.85 & 3.86 & 0.2 & 5.75 & 1.1 & 8.11 & 44.57 & 41.03 & 50.28 & 41.25 \\
\hline 0.5 & $\mathrm{Ca}_{0.5} \mathrm{La}_{0.5} \mathrm{NiAl}_{11} \mathrm{O}_{19}-\delta$ & 2.72 & 2.68 & 0.48 & 9.32 & 1.13 & 7.87 & 44.1 & 39.85 & 51.57 & 40.28 \\
\hline 0.7 & $\mathrm{Ca}_{0.3} \mathrm{La}_{0.7} \mathrm{NiAl}_{11} \mathrm{O}_{19}-\delta$ & 1.9 & 1.56 & 0.88 & 12.68 & 1.2 & 7.65 & 44.1 & 38.74 & 51.92 & 39.37 \\
\hline 0.9 & $\mathrm{Ca}_{0.1} \mathrm{La}_{0.9} \mathrm{NiAl}_{11} \mathrm{O}_{19}-\delta$ & 1.04 & 0.51 & 1.24 & 15.86 & 1.28 & 7.45 & 44.5 & 37.69 & 51.94 & 38.49 \\
\hline 1 & $\mathrm{LaNiAl}_{11} \mathrm{O}_{19}-\delta$ & - & - & 1.44 & 17.39 & 1.6 & 7.35 & 45.0 & 37.19 & 51.87 & 38.07 \\
\hline
\end{tabular}

4 Catalytic Activity of $\mathrm{Ca}_{1-x} \mathrm{La}_{x} \mathrm{NiAl}_{11} \mathrm{O}_{19-\delta}$ Hexaaluminates in Dry Reforming of Methane

The activity of reduced $\mathrm{Ca}_{1-x} \mathrm{La}_{x} \mathrm{NiAl}_{11} \mathrm{O}_{19-\delta}$ is given Fig. 5 between 500 and $900{ }^{\circ} \mathrm{C}$. No clear correlation was observed between $\mathrm{CO}_{2}$ or $\mathrm{CH}_{4}$ reactivity and $\mathrm{Ca} / \mathrm{La}$ ratio. Even with the low amount of $\mathrm{Ni}$ present at the surface (XPS results), all the catalysts present a high activity following thermodynamic data except for $\mathrm{Ca}=0.3$ and 0.7. Activity is the highest for $\mathrm{Ca}_{0.5} \mathrm{La}_{0.5} \mathrm{NiAl}_{4} \mathrm{O}_{19-\delta}$ which is not the catalyst with the highest content of surface nickel but the catalyst with the highest reducibility (see Table 1).
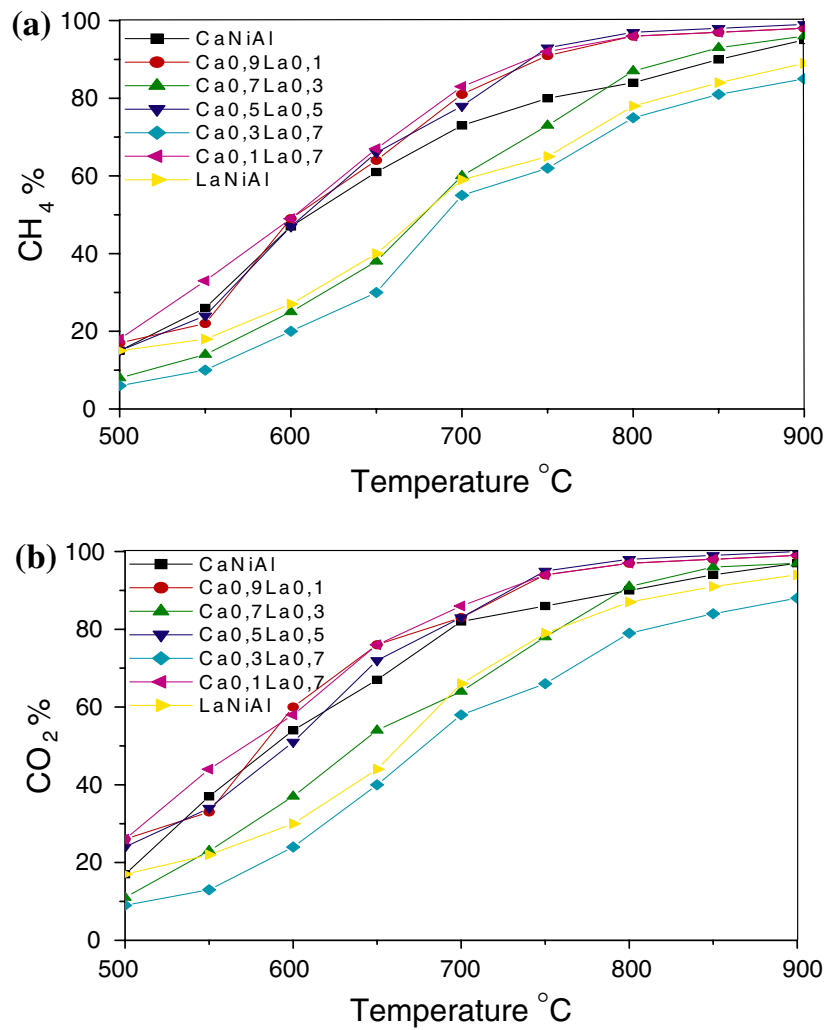

Fig. 5 Temperature dependence of catalytic activity over $\mathrm{Ca}_{1-x} \mathrm{La}_{x} \mathrm{NiAl}_{11} \mathrm{O}_{19-\delta}$
The $\mathrm{H}_{2} / \mathrm{CO}$ ratio is always near 1 except for $\mathrm{Ca}=0.3$. Formation of carbonaceous species is given (Fig. 6) and characterized by TPO. All the catalysts present three main peaks: one is located between 540 and $590{ }^{\circ} \mathrm{C}$. It corresponds to surface carbon deposited as nanotubes on the catalyst. The second one is located between 440 and $455{ }^{\circ} \mathrm{C}$ and could be tentatively attributed to carbon located at the vicinity rare earth at of metal and rare earth [18]. It appears like a shoulder of the first one. The third one is located between 330 and $370{ }^{\circ} \mathrm{C}$. Surface area is increasing with the percentage of lanthanum. It could be attributed at the presence of surface carbonates.
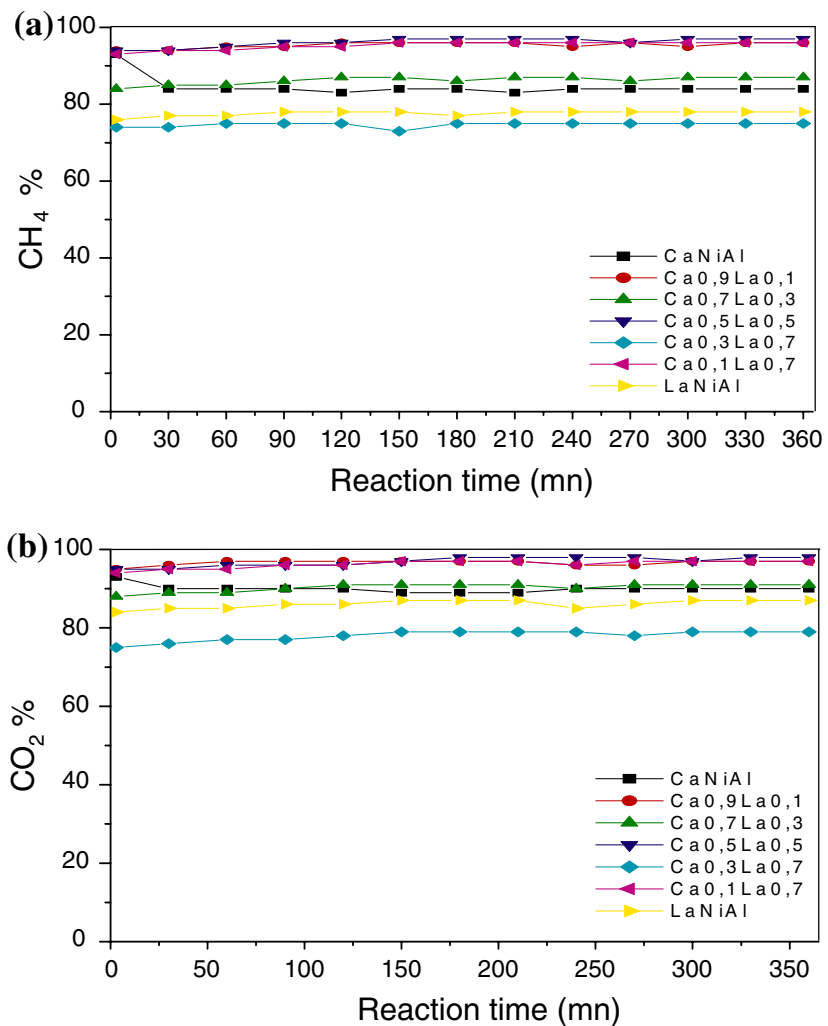

Fig. 6 Peak temperature assignments and total carbon deposited obtained by TPO 


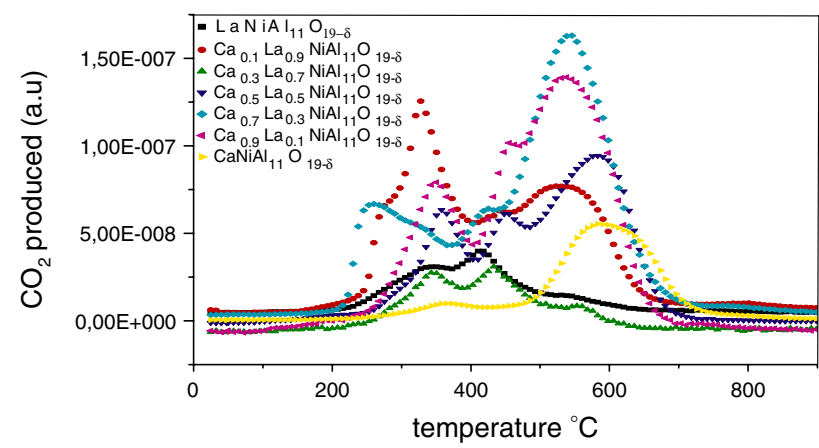

Fig. 7 Stability of $\mathrm{Ca}_{1-x} \mathrm{La}_{x} \mathrm{NiAl}_{11} \mathrm{O}_{19-\delta}$ catalysts

Finally the stability of the catalysts has been investigated at $800{ }^{\circ} \mathrm{C}$ during $6 \mathrm{~h}$ (Fig. 7), again $\mathrm{Ca}_{0.5} \mathrm{La}_{0.5-}$ $\mathrm{NiAl}_{11} \mathrm{O}_{19-\delta}$ is the most active for $\mathrm{CH}_{4}$ and $\mathrm{CO}_{2}$ conversion, $\mathrm{Ca}=0.3$ given the lowest activity. It should be noticed that in absence of $\mathrm{La}$, the CaNiAl catalyst lost quickly some activity.

\section{Conclusion}

A series of substituted $\mathrm{Ca}_{1-x} \mathrm{La}_{x} \mathrm{NiAl}_{11} \mathrm{O}_{19-\delta}$ hexaaluminates were prepared using citric acid method. All the obtained solids have low surface area after calcination at $1,100{ }^{\circ} \mathrm{C}$. As soon lanthanum is present, the formation of hexaaluminate has been confirmed by XRD. After reduction, content of $\mathrm{Ni}$ at the catalytic surface is low. However, all the catalysts and more specifically $\mathrm{Ca}_{0.5} \mathrm{La}_{0.5} \mathrm{NiAl}_{11} \mathrm{O}_{19-\delta}$ which has the highest percentage of Ni reduced at the surface (XPS) shows high activity for syngas production but also high stability for the reaction $(300 \mathrm{~h})$.
Open Access This article is distributed under the terms of the Creative Commons Attribution Noncommercial License which permits any noncommercial use, distribution, and reproduction in any medium, provided the original author(s) and source are credited.

\section{References}

1. BP Statistical Review of World Energy (2008)

2. Hu YH, Ruckenstein E, Bruce CG, Helmut K (2004) Adv Catal 48:297

3. Basile F, Fornasari G, Trifiro F, Vaccari A (2002) Catal Today 77:215

4. Ruckenstein E, Hu YH (1995) Appl Catal A 133:149

5. Ruckenstein E, Hu YH (1999) Appl Catal A 183:85

6. Provendier H, Petit C, Estournes C, Libs S, Kiennemann A (1999) Appl Catal A 180:163

7. Djaidja A, Libs S, Kiennemann A, Barama A (2006) Catal Today 113:194

8. Sahli N, Petit C, Roger AC, Kiennemann A, Libs S, Bettahar MM (2006) Catal Today 113:187

9. Romera-Saria F, Vargas JC, Roger AC, Kiennemann A (2008) Catal Today 133-135:149

10. Gallego GS, Batiot-Dupeyrat C, Barrault J, Florez E, Mondragon F (2008) Appl Catal A 334:251

11. Rostrupp-Nielsen JR, Schested J, Norskov JK (2002) Adv Catal 47:65

12. Liu Y, Xu Z, Li D, Chen T, Zhou G, Li W, Bi Y, Zhen K (2002) Kinet Catal 43:522

13. Liu Y, Cheng T, Li D, Jiang P, Wang J, Li W, Bi Y, Zhen K (2003) Catal Lett 85:101

14. Li S, Liu H, Yan L, Wang X (2007) Catal Comm 8:237

15. Xu Z, Zhen M, Bi Y, Zhen K (2000) Appl Catal A 198:267

16. Xu Z, Zhen M, Bi Y, Zhen K (2000) Catal Lett 64:157

17. Gardner TH, Shekhawat D, Berry DA, Smith MW, Salazar M, Kugler EL (2007) Appl Catal A Gen 323:1

18. Zhu T, Flytzani-Stephanopoulos M (2001) Appl. Cat. A 208:403 